\title{
Inner retinal dehiscence and macular microhole secondary to vitreomacular traction
}

\author{
Hirawat Rajshri, ${ }^{1}$ CK Nagesha, ${ }^{2}$ Pratyusha Ganne ${ }^{3}$
}

${ }^{1}$ Vitreo-Retina, Gomabai Nethralaya and Research Centre, Neemuch, India

${ }^{2}$ Department of Vitreo-Retina, B W Lions Superspeciality Eye Hospital, Bangalore, India ${ }^{3}$ Ophthalmology, All India Institute of Medical Sciences, Guntur, India

\section{Correspondence to} Dr Hirawat Rajshri; drrajshreehirawat@gmail.com

Accepted 20 October 2020

Check for updates

(c) BMJ Publishing Group Limited 2020. No commercial re-use. See rights and permissions. Published by BMJ.

\begin{tabular}{l}
\hline To cite: Rajshri H, \\
Nagesha CK, Ganne P. BMJ \\
Case Rep 2020;13:e239480. \\
doi:10.1136/bcr-2020- \\
239480 \\
\hline
\end{tabular}

\section{DESCRIPTION}

Macular microholes are focal defects in the ellipsoid zone which occur in the foveal area. They are caused by prolonged sun gaze, trauma, welding arc exposure, tamoxifen use and vitreomacular traction. ${ }^{12}$ Isolated presence of microhole during clinical evaluation without a history of the above exposures poses a diagnostic challenge. We report the utility of optical coherence tomography (OCT) imaging in a case of macular microhole secondary to vitreomacular traction

A 51-year-old woman was evaluated for poor vision in the left eye (LE) for 3 months. Her bestcorrected vision was $6 / 6$ in the right eye and 6/18 in the LE. The fundus examination (figure 1A) of the LE showed a blunted foveal contour with a central yellow spot (inset). OCT scans across the fovea showed a parafoveal anteroposterior vitreous traction over inner retinal layers (vitreomacular traction). This resulted in inner retinal dehiscence (bat-shaped) and outer retinal hole (figure 1B). The external limiting membrane was seen bridging between the outer retinal hole and the inner retinal dehiscence. The right eye fundus and OCT were normal.

Identifying the aetiology of macular microholes is important to predict the visual prognosis and plan management. Posterior vitreous detachment and vitreoretinal interface changes were probably the most commonly associated conditions. ${ }^{3}$ The oblique course of the Henle' fibre layer and poor Muller cell support in the fovea may provide a weaker infrastructure against the tangential vitreous traction. This then causes intraretinal splitting or a pseudocyst formation followed by photoreceptor loss. ${ }^{4}$ Symptoms of PVD, irregular foveal pit on OCT, dense posterior vitreous in front of fovea hints at probable aetiology of PVD. They often close spontaneously with good visual prognosis except in cases with persistent vitreomacular traction as in the present case. The identification of underlying aetiology is important to prognosticate and to plan management. Intraretinal clumps with eccentric retinal pseudocysts may be seen in macular telangiectasia which has a poor visual prognosis. Epiretinal membranes as a cause for outer retinal defects can be easily detected and OCT helps in decision-making for surgical membrane removal. Smaller microholes secondary to trauma close spontaneously but larger holes may persist or progress to full-thickness holes and need surgical intervention. History of sun gaze, welding arc exposure and drug intake hint at specific aetiology. Such microholes may be associated with cone degeneration

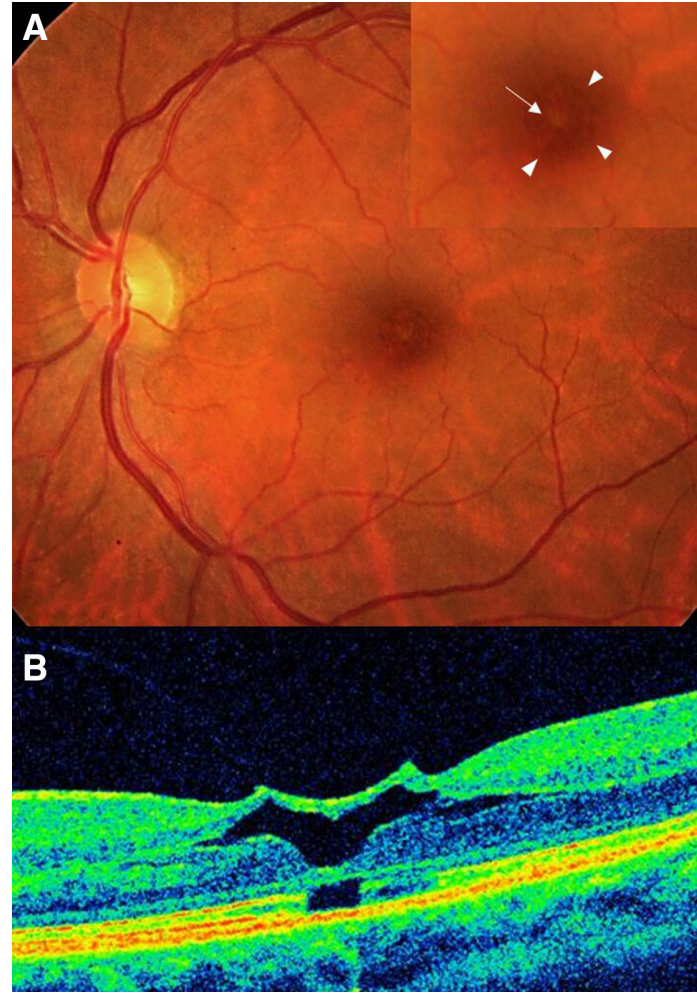

Figure 1 (A) Fundus photograph showing a central irregular foveal contour (arrow heads) and central yellow spot (arrow). (B) OCT through the fovea showing a batshaped inner retinal dehiscence and an outer retinal hole involving the ellipsoid zone and cone outer segments. The external limiting membrane appears intact.

and hence vision remains subnormal. ${ }^{5}$ Recently, the pachychoroid spectrum was speculated to be strongly associated with outer retinal defects and OCT can be used to demonstrate thick subfoveal

\section{Learning points}

Vitreomacular traction is one of the aetiological causes for unilateral or bilateral microhole formation and inner retinal dehiscence.

- Demonstration of vitreomacular traction on optical coherence tomography confirms the aetiopathogenesis of microhole formation.

- Often complete detachment of posterior vitreous results in resolution of inner retinal dehiscence and closer of macular microhole.

- Timely surgical intervention may be needed if it persists or progresses to full-thickness macular hole. 
choroid. ${ }^{3}$ In the present case, vitreomacular traction on OCT helped in arriving at the right diagnosis and helped us to monitor closely for any progression or resolution of retinal dehiscence and microhole.

Contributors HR: case documentation and content idea. NCK: literature search and manuscript preparation. PG: manuscript review and editing and proof reading.

Funding The authors have not declared a specific grant for this research from any funding agency in the public, commercial or not-for-profit sectors.

Competing interests None declared.

Patient consent for publication Obtained.

Provenance and peer review Not commissioned; externally peer reviewed.

\section{REFERENCES}

1 Comander J, Gardiner M, Loewenstein J. High-resolution optical coherence tomography findings in solar maculopathy and the differential diagnosis of outer retinal holes. Am J Ophthalmol 2011;152:413-9.

2 Ooto S, Hangai M, Takayama K, et al. High-resolution imaging of photoreceptors in macular microholes. Invest Ophthalmol Vis Sci 2014;55:5932-43.

3 Azzolini C, Patelli F, Brancato R. Correlation between optical coherence tomography data and biomicroscopic interpretation of idiopathic macular hole. Am J Ophthalmol 2001;132:348-55

4 Cohen SY, Mrejen S, Nghiem-Buffet S, et al. Outer foveal micro-defects. Ophthalmol Retina 2020.

5 Steel DHW, Lotery AJ. Idiopathic vitreomacular traction and macular hole: a comprehensive review of pathophysiology, diagnosis, and treatment. Eye 2013;27:S1-21.

Copyright 2020 BMJ Publishing Group. All rights reserved. For permission to reuse any of this content visit https://www.bmj.com/company/products-services/rights-and-licensing/permissions/

BMJ Case Report Fellows may re-use this article for personal use and teaching without any further permission.

Become a Fellow of BMJ Case Reports today and you can:

Submit as many cases as you like

- Enjoy fast sympathetic peer review and rapid publication of accepted articles

- Access all the published articles

- Re-use any of the published material for personal use and teaching without further permission

Customer Service

If you have any further queries about your subscription, please contact our customer services team on +44 (0) 2071111105 or via email at support@bmj.com.

Visit casereports.bmj.com for more articles like this and to become a Fellow 